\title{
A FOSSIL BOLSTER PLANT FROM THE KING RIVER, TASMANIA
}

\author{
by N. Gibson, K.W. Kiernan and M.K. Macphail
}

(with two tables, two text-figures and three plates)

\begin{abstract}
GIBSON, N., KIERNAN. K.W. \& MACPHAIL, M.K., 1987 (30:vi): A fossil bolster plant from the King River, Tasmania. Pap. Proc. R. Soc. Tasm., 121:35-42. https://doi.org/10.26749/rstpp.121.35 ISSN 0080-4703. Departments of Geography and Botany (N.G.), Department of Geography (K.W.K.) and Department of Botany (M.K.M.), University of Tasmania, Hobart, Tasmania.

A macrofossil of the alpine bolster plant Donatia novae-zelandiae was found in the King River Valley, approximately $230 \mathrm{~m}$ above sea level in central western Tasmania. The fossil was in situ on a palaeosol that appears to have formed immediately prior to the late Last Glacial Maximum. An age of $21180+370$ years b.p. was established by radiocarbon dating. Pollen and present day distributional data suggest that the tree line was then at least $750 \mathrm{~m}$ lower than at present, implying a temperature depression of about $4.5^{\circ} \mathrm{C}$. Scanning electron-micrographs and photomicrographs of the extant and fossil bolster species are presented.
\end{abstract}

Key Words: Tasmania, bolster, Donatia, fossil, palaeosol.

\section{INTRODUCTION}

Bolster plants are chamaephytes with a very compact growth habit, the branches being closely packed, with short internodes forming a hard hemispherical surface. This growth form is common in alpine areas of Tasmania, New Zealand, South America and some of the sub-Antarctic Islands (Godley 1978). The bolster form is poorly developed in the alpine areas of mainland Australia. The term bolster is preferred to cushion to indicate the hard compact nature of this growth form compared with Northern Hemisphere species of cushion plants.

In Tasmania there are four major species of bolster plant, Abrotanella forsteroides (Hook.f.) Benth. (Asteraceae), Dracophyllum minimum (Epacridaceae), Phyllachne colensoi (Stylideaceae) and Donatia novae-zelandiae (Donatiaceae). These species are initially difficult to distinguish in the field in the vegetative phase. They can form hard cushions up to $3.0 \mathrm{~m}$ diameter and $0.5 \mathrm{~m}$ tall. Distribution patterns found in these species have been described by Martin (1S.+v), Jackson (1972), Kirkpatrick $(1977,1980,1982,1983)$ and Kirkpatrick \& Harwood (1980), Brown et al. (1983), Kirkpatrick \& Gibson (1984) and Gibson \& Kirkpatrick (1985a,b).

The difficulty of ascribing the terms alpine and subalpine to the high altilude treeless areas of Tasmania, where treelines are generally absent, has been discussed by Kirkpatrick (1982). Notwithstanding this, bolster plant distribution in Tasmania is generally described as alpine with incursions below the climatic treeline in areas subject to cold air drainage and poor soil drainage. This paper records a macrofossil of the cushion plant Donatia novae-zelandiae from the King River Valley approximately $750 \mathrm{~m}$ below the present climatic treeline in central western Tasmania, and discusses its stratigraphic context and its significance in relation to present day distributional patterns.

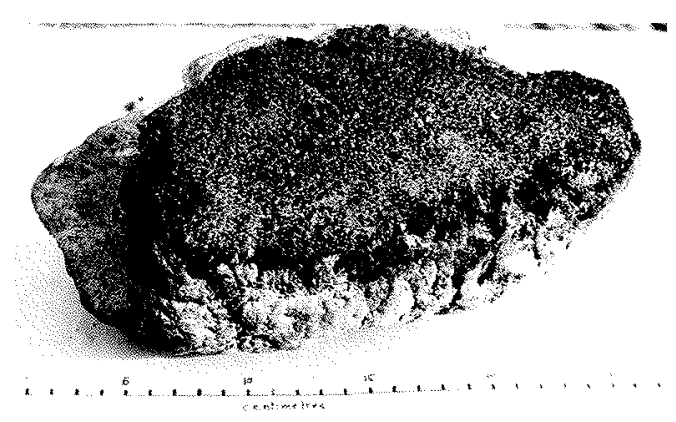

PLATE 1 - Photograph of a fossil Donatia novae-zelandiae cushion (21 180 years b.p.) from the Dante Rivulet site.

\section{METHODS}

The $200 \mathrm{~mm}$ diameter fossil was collected during an investigation of the glacial chronology of the central West Coast Range. It was obtained from a $5 \mathrm{~m}$ deep section cut by the King River a 
short distance downstream from its confluence with the Dante Rivulet at about $230 \mathrm{~m}$ ASL (plate 1 , figs 1 and 2). By this means it was possible to relate the fossil Donatia to the regional lithostratigraphy and chronostratigraphy. The immediate area has been subject to repeated firing, the present vegetation consisting of heathy sedgeland with riparian strips of mixed forest.

Positive identification of the fossil was carried out using both cuticular analysis and scanning electron microscopy of the leaf surface. Leaf fragments were initially soaked in hydrofluoric acid for 24 hours to remove siliceous material. The most intact fragments were mounted for scanning electron microscopy. The remaining material was cleared with nitric acid, and the cuticles prepared by soaking in nitric acid and potassium chlorate neutralising with aqueous ammonia and finally staining with safranin $\mathrm{O}$ and mounting. Comparative slides of all four extant bolster species were similarly prepared.

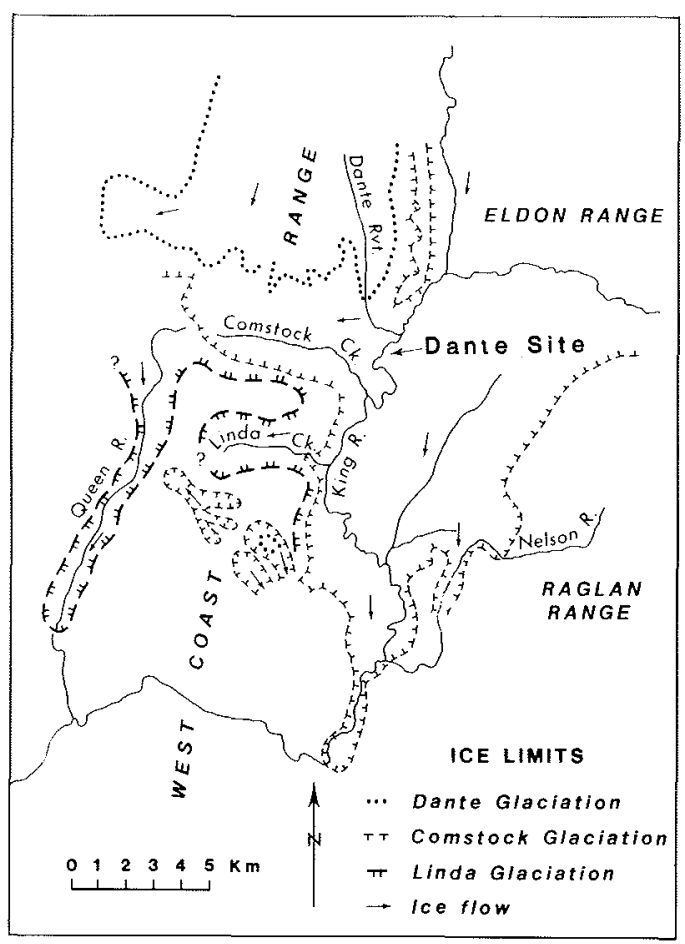

FIG. 1 - Topographic relationships and Quaternary ice limits near the Dante Rivulet site in the central West Coast Range (after Kiernan, 1983a).
A spot pollen sample was taken from the organic silts at the downstream end of the palaeosol. Pollen and spore types were extracted using standard palynological techniques (Faegri \& Iverson 1975).

Species nomenclature follows Curtis (1963, 1967) and Curtis \& Morris (1975), unless otherwise stated.

\section{RESULTS \\ Stratigraphy}

The exposed profile is shown in figure 2. The lowermost metre of the section consists of coarse gravels and gritty sand that probably represent part of the Comstock Formation but could be more recent. It is believed to represent glacial outwash derived from an ice body which lay a short distance upstream in the King Valley. This unit is unconformably overlain by $0.15 \mathrm{~m}$ of very dark brown (7.5 YR2/3) organic silt at the base of which abundant macrofossils were found including small branchlets which are believed to have been river transported. The spot pollen sample taken from this unit indicates an Asteraceae-Poaceae assemblage (table 1).

A weakly developed podsolic palaeosol occurs upon this silt unit. The intact cushion macrofossil was about $0.2 \mathrm{~m}$ in diameter and was found in situ on the palaeosol. The palaeosol is in turn overlain by $0.45 \mathrm{~m}$ of slightly discoloured yellowish grey $(2.5$ Y5/1) silt and fine sands which were probably rapidly deposited in an aquatic environment. The cushion plant itself has been radiocarbon dated at $21180 \pm 370$ years b.p. (SUA2154). A $0.2 \mathrm{~m}$ piece of driftwood was recovered from $0.1 \mathrm{~m}$ above the palaeosol and dated at $18800 \pm 500$ years b.p. (ANU2533). A further date of $20100 \pm 470$ years B.P. (SUA2155) has been obtained from twigs incorporated in a silt bed that overlies the Comstock gravels about $100 \mathrm{~m}$ downstream from the fossil cushion. This silt is believed to be equivalent to that immediately beneath the cushion plant, but exposure is discontinuous and this relationship remains unproven (Kiernan 1980, 1985).

A further $0.35 \mathrm{~m}$ of yellowish grey $(2.5 \mathrm{Y} 6 / 1)$ fine sand and silt is succeeded by three metres of gravels of the Dante Formation which are interpreted as glacial outwash from a new ice advance in the tributary Dante Rivulet. The section is overlain by a metre of peat (Kiernan 1980, 1983a).

\section{Pollen Analysis}

Table 1 lists pollen and spore types extracted from the organic silt. Included against each taxon 


\section{TABLE 1}

\section{Spot pollen sample from Dante palaeosol and an estimate of pollen production/dispersal characteristics.}

$\mathrm{NI}=$ no information, $\mathrm{SU}=$ severely under-represented, $\mathrm{U}=$ underrepresented, $\mathrm{W}=$ well to over-represented.

\begin{tabular}{|c|c|c|}
\hline Pollen Taxon & Percentage & $\begin{array}{c}\text { Pollen } \\
\text { Dispersal }\end{array}$ \\
\hline Isoetes & + & NI \\
\hline Lycopodium deuterodensum & + & U \\
\hline L. scariosum & 1.0 & W \\
\hline Gleichenia & 14.0 & U \\
\hline Microstrobos & + & NI \\
\hline Casuarina type & 2.0 & W \\
\hline Chenopodiaceae & 2.0 & W \\
\hline Compositae & $20.0(3.0)$ & W \\
\hline Donatia & 2.0 & SU \\
\hline Epacridaceae T-type & 9.0 & SU \\
\hline Leucopogon type & + & U \\
\hline Monotoca & + & NI \\
\hline Nothofagus fusca type & + & W \\
\hline Eucalyptus & 2.0 & W \\
\hline Melaleuca & + & W \\
\hline Papilionaceae & $+\mathrm{U}$ & \\
\hline Bellendena & + & NI \\
\hline Orites & + & $\mathrm{U}$ \\
\hline Coprosma & + & W \\
\hline Rutaceae cf. Phebalium & + & NI \\
\hline Cyperaceae & 9.0 & W \\
\hline Drosera arcturi & + & NI \\
\hline Gentianaceae cf. Centaurium & + & NI \\
\hline Gentianella & + & NI \\
\hline Goodeniaceae & + & W \\
\hline Gramineae & 17.0 & W \\
\hline Gunnera & + & SU \\
\hline Astelia & + & NI \\
\hline Lobeliaceae cf. Lobelia & + & NI \\
\hline Plantago & + & $\mathrm{U}$ \\
\hline Anemone & + & $\mathrm{NI}$ \\
\hline Ranunculus & + & SU \\
\hline Restionaceae & 4.0 & $\mathrm{U}$ \\
\hline Scrophulariaceae cf. & + & NI \\
\hline Umbelliferae Indet. & 8.0 & SU \\
\hline Pollen sum: & 64.8 & \\
\hline
\end{tabular}

() refers to short echinate type probably extinct.

is an estimate of the pollen production/dispersal characteristics (=representivity) of the source plant(s) (cf. Macphail \& McQueen 1983). All percentags are expressed relative to a pollen sum comprising the well-dispersed types (Macphail 1975).

Although the concentration of palynomorphs was low, 35 pollen types could be identified to a family or genus. The majority of these are herbs and, assuming the sources of the composite pollen were largely herbaceous, then herbs and pteridophytes constitute $70 \%$ of the pollen sum: Compositae (20\%), Gramineae (17\%), Gleichenia (14\%), Cyperaceae plus Restionaceae (13\%) and U mbelli- 

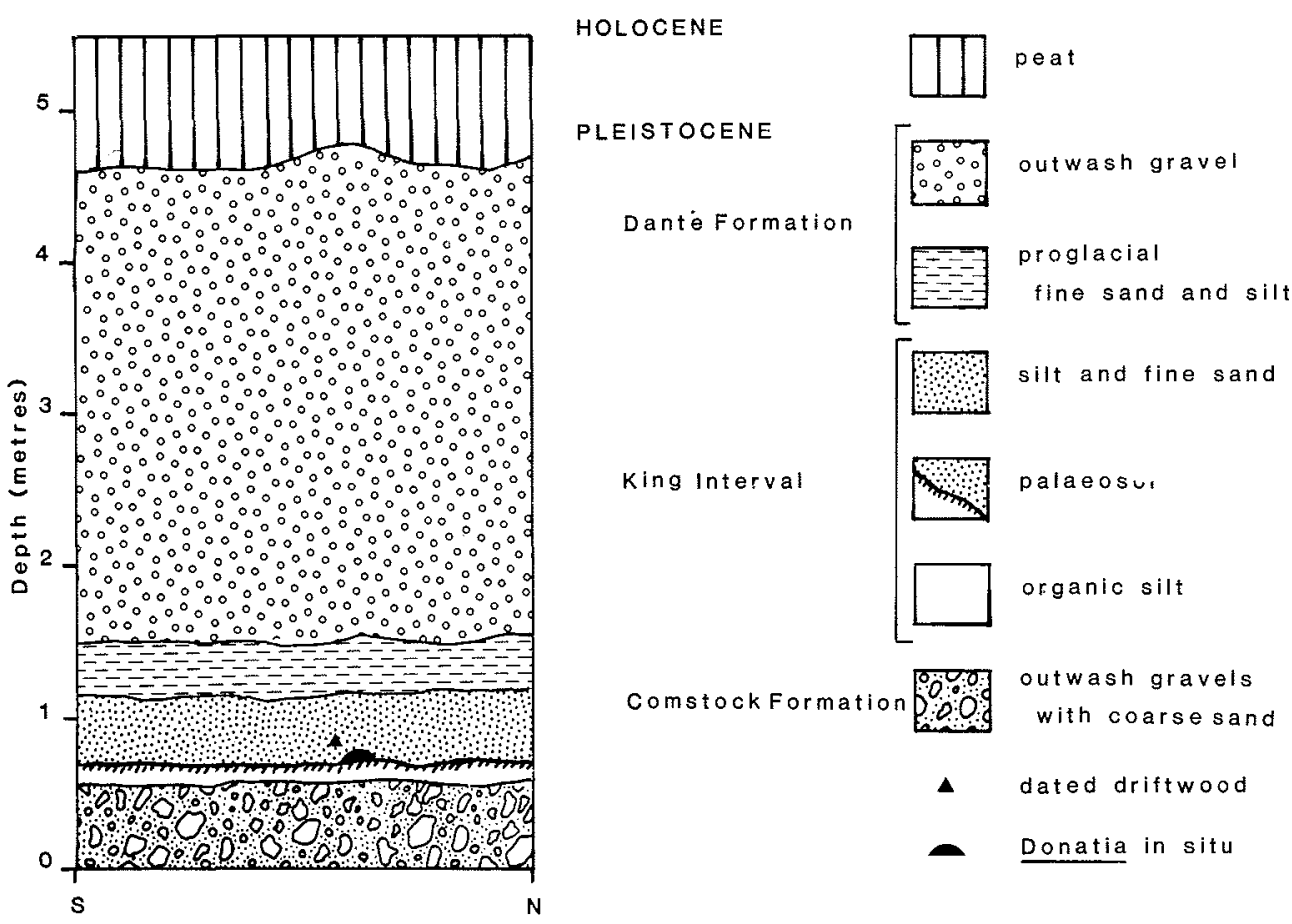

FIG.2 - Stratigraphy of section cut by the King River with locations.

ferae $(8 \%)$. Woody types are comparatively infrequent with Epacridaceae (9\%), Eucalyptus, Casuarina and Donatia (all 2\%) being the most abundant. With the exception of Microstrobos and Nothofagus gunnii ( $N$. fusca type), both of which have their main centres of distribution close to or above the timberline, pollen of rainforest taxa are absent. The 2\% Donatia pollen is amongst the highest values of this type recorded to date in either fossil or modern assemblages in Tasmania (Macphail 1979, unpublished results, cf. fig. 3 in Colhoun 1985a).

\section{Donatia Macrofossil}

The photomicrographs of the cuticle and the electron micrographs of the leaf surface of the fossil are almost identical in detail with those of extant Donatia novae-zelandiae (plate 2), though somewhat smaller in size. Both show a distinctive raised cuticular ridge around the stomata. The leaf tips of both are bluntly acuminate. The typical dense tufts of axil hairs of D. novae-zelandiae are apparent in the cuticle preparations of the fossil.

Plate 3 ( $A$ to $F$ ) shows the distinctive patterns of surface cuticle, cell wall arrangement and gross stomatal size and pattern for the other three species of bolster plant. Electron micrographs of the leaf aprces of these species also show distinctive differences.

Dracophyllum minimum is roughly triangular in cross-section near the leaf apex with each edge minutely serrate ending in an acute point. The stomata are very small, less than $15 \mu \mathrm{m}$ long and epidermal cells have highly distinctive sinuous walls.

Phyllachne colensoi has an obtuse apex with a glandular pore just below it, on the abaxial surface (Curtis 1963). The cuticle is very thin and the electron micrograph shows evidence of localized collapse.

Abrotanella forsteroides has a distinctive acuminate often recurved hair-like apex with obscurely blunt serrulate leaf margins. Stomata are arranged in bands around the leaf converging toward the apex. The photomicrograph (plate $3 F$ ) of one of these bands shows the thickened walls of epidermal cells and the electron micrograph (plate 3E) shows imprints of stomata in cuticle from the closely appressed imbricate leaves.

\section{DISCUSSION}

The Comstock Glaciations are considered to predate the Last Glacial Stage on morphologic, 
stratigraphic and weathering evidence at several sites in the central West Coast Range (table 2). The silts which unconformably overlie the Comstock gravels at this section have been only weakly modified by pedogenesis. The grey silt which overlies the palaeosol is interpreted as having been rapidly deposited in an aquatic environment. The upper silts represent renewed glacigenic sedimentation in a surface depression after a time break. The radiocarbon dates indicate that the Dante outwash gravels represent the late Last Glacial maximum (Kiernan 1980, 1983b).
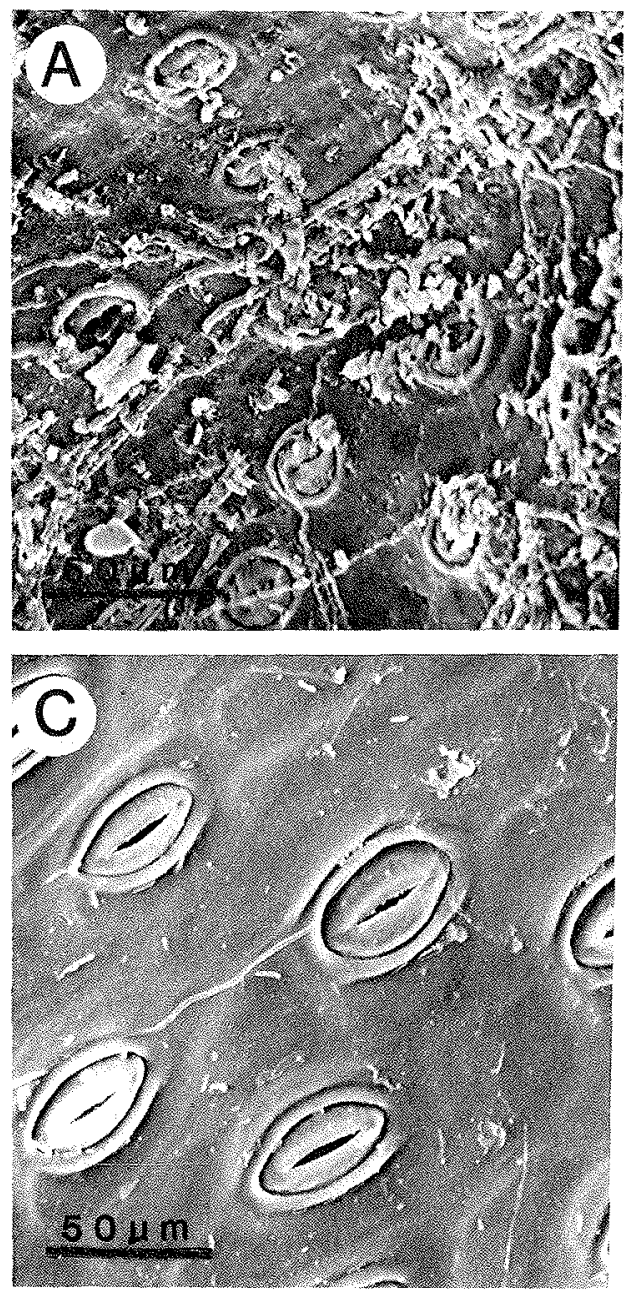

Both the macrofossil and microfossil evidence suggest that a cold climate, species-rich herbfield bog mosaic occupied the site during the period represented by the organic silt. Rainforest was absent and sclerophyll trees rare within the region, with the latter possibly occurring in shrub form.

Although this interpretation is ecologically consistent with current reconstructions of full glacial climates in western Tasmania (Macphail 1975, Macphail \& Colhoun 1985), caution is required for several reasons. Firstly, the pollen sample is an isolated one and possibly unrepresen-
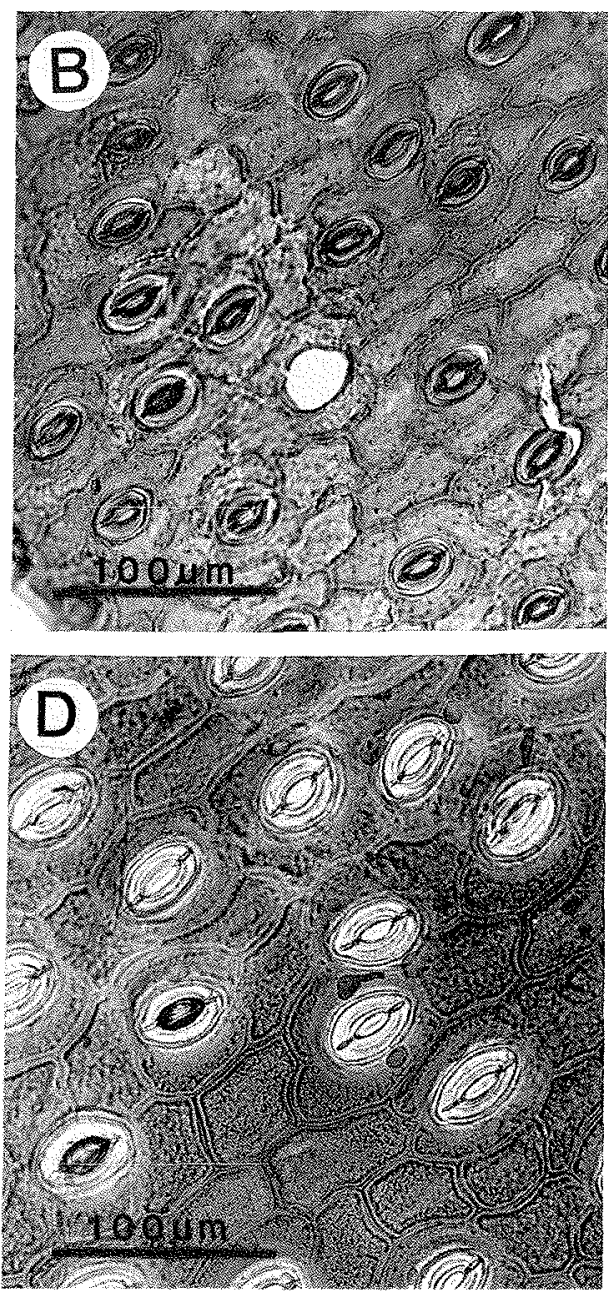

PLATE2 - A, scanning electron micrograph of the fossil leaf surface; $B$, cuticular photomicrograph of the fossil showing guard cells and irregularly shaped epidermal cells; $C$, scanning electron micrograph of extant Donatia novae-zelandiae leaf surface showing distinctive raised subsidiary cells; $D$, cuticular photomicrographs of extant Donatia novae-zelandiae. 

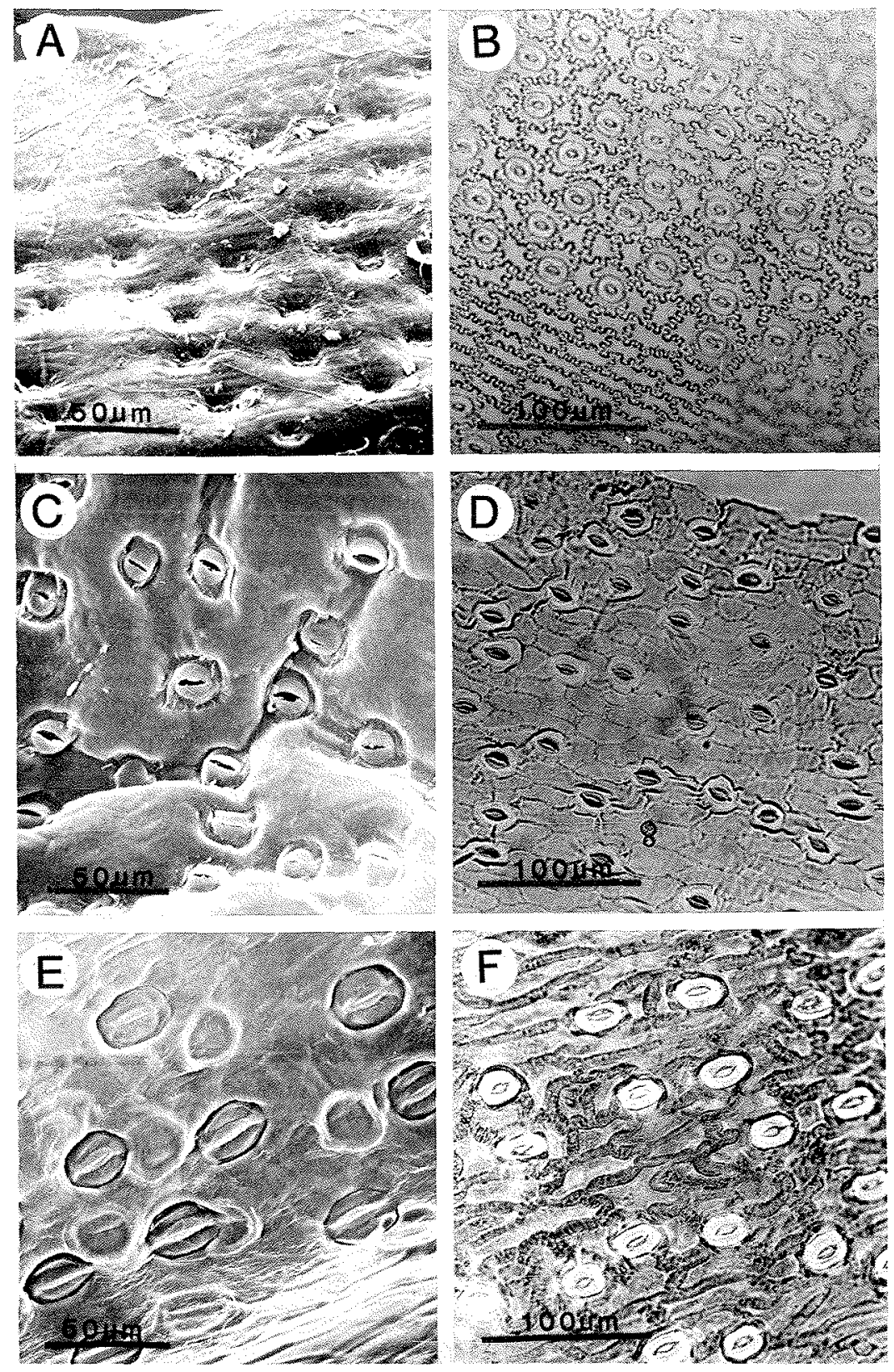

PLATE $3-A$, scanning electron micrograph of extant Dracophyllum minimum showing small deep stomatal pits; $B$, cuticular photomicrograph of extant Dracophyllum minimum showing small stomata and highly distinctive sinuous epidermal cell walls; $C$, scanning electron micrograph of extant Phyllachne colensoi showing thin cuticle with some local collapse; $D$, cuticular photomicrograph of extant Phyllachne colensoi showing very thin nature of epidermal cell walls; $E$, scanning electron micrograph of one of the bands of stomata of extant Abrotanella forsteroides showing impressions of stomata from closely appressed leaves; $F$, cuticular photomicrograph of extant Abrotanella forsteroides showing distinctive stomatal band and highly thickened epidermal cell walls. 
TABLE 2

Nomenclature and probable correlation of glacial events in the West Coast Range.

\author{
King Drainage \\ System
}

(Kiernan 1980, 1983a)

\author{
Henty Drainage \\ System \\ (Colhoun 1985b)
}

Pieman Drainage

System

(Sansom 1978,

Augustinus 1982)

Margaret

Glaciation

\begin{tabular}{llll}
\hline $\begin{array}{l}\text { Last Late Glacial } \\
\text { Stage }\end{array}$ & $\begin{array}{l}\text { Dante } \\
\text { Glaciation }\end{array}$ & $\begin{array}{l}\text { Margaret } \\
\text { Glaciation }\end{array}$ & $\begin{array}{l}\text { Margaret } \\
\text { Glaciation }\end{array}$ \\
$\begin{array}{l}\text { Stage } \\
\text { Pre Last Interglacial }\end{array}$ & Comstock & Henty & Boco I \& Boco II \\
Glacial Stage(s) & Glaciations & Glaciation & Glaciations \\
Late Pliocene/Early & Linda & Linda & Bulgobac I \& \\
Pleistocene Glacial & Glaciations & Glaciation & Bulgobac II \\
Stage(s) & & Glaciations \\
\hline
\end{tabular}

tative. Secondly, all pollen assemblages are only a partial record of past floras with some indication of abundance (Macphail \& McQueen 1983). Thirdly, either extremely rapid accumulation of sediments or in situ growth of a "strong" pollen source may result in the dilution of all or part of the pollen influx, particularly long distance transported types. Neither is considered likely given the high organic content of the silt and abundance of severely underrepresented species such as Donatia novae-zelandiae, but such considerations are likely to be applicable to any palynofloras recovered from the overlying silts and sands.

The section therefore is interpreted as demonstrating the formation of a tundra soil during a period when the treeline lay below $230 \mathrm{~m}$. Donatia novae-zelandiae can occasionally occur to low elevations in areas of reduced plant competition. In New Zealand it occurs at sea level in the far south, and in western Tasmania down to $80 \mathrm{~m}$ in the Harwood Valley (M.J. Brown, pers. comm. 1983), both in very acid peats. The pollen data strongly suggest a tundra vegetation rather than a valley bog.

Probably the strongest evidence that the reconstruction of the vegetation is correct comes from the close match between the Dante Rivulet assemblage and other near or full glacial period palynofloras recorded in lowland western Tasmania, notably those at Henty Bridge near Queenstown. There Colhoun (1985a) has recorded (subzone $\mathrm{HB} 2$, from the top of a unit of lacustrine clays and silts overlying glacial sediments) a GramineaeAsteraceae-Restionaceae-Cyperaceae assemblage containing significant amounts of Epacridaceae, Gleichenia and Lycopodium. The major difference is that pollen of Cruciferae occurs in significant a mounts whilst Umbelliferae are rare. As at Dante, sclerophyll tree pollen is relatively infrequent at Henty Bridge and rainforest tree pollen such as Nothofagus cunninghami virtually absent except in the highest sample (immediately underlying a weathered slope deposit). Colhoun dates this zone as $20-21$ kyr b.p., based on a radiocarbon date of 23640 b.p. from the underlying silts (samples of which contain between $5-10 \%$ N. cunninghami and $10-40 \%$ of Microstrobos niphophiluspollen).

Data from Kirkpatrick (1982) indicate that the present climatic treeline in this area of the West Coast lies at $975 \mathrm{~m}$. The fossil Donatia and associated pollen evidence suggest minimum depression of the treeline by $750 \mathrm{~m}$ assuming this site was at or above the treeline. If the standard lapse rate of $0.6^{\circ} \mathrm{C} / 100 \mathrm{~m}$ is assumed, this suggests that mean annual temperature was depressed by $4.5^{\circ} \mathrm{C}$ below its present value at this location at approximately 20000 years B.P.

\section{ACKNOWLEDGEMENTS}

We would like to thank Dr J.B. Kirkpatrick for his comments, Dr R.S. Hill for advice on cuticle preparation, Professor E.A. Colhoun for his advice in the field and $\mathrm{Mr} \mathrm{W}$. Jablonski for help with the electron microscopy. The radiocarbon dating was funded by the Geography Department, University of Tasmania. 


\section{REFERENCES}

AUGUSTINUS, P., 1982: THE GLACIAL GEOMORPHOLOGY OF THE MIDDLE PIEMAN$B U L G O B A C A R E A$. Unpubl. Honours thesis, University of Tasmania.

BROWN, M.J., KIR KPATRICK, J.B. \& MOSCAL, A., 1983: AN ATLAS OF TASMANIA'S ENDEMIC FLORA. Tasmanian Conservation Trust, Hobart.

COLhOUN, E.A., 1985a: Pre-Last Glaciation Maximum vegetation history at Henty Bridge, western Tasmania. New Phytol., 100; 681-690.

COLHOUN, E.A., 1985b: Glaciation of the West Coast Range, Tasmania. Quat. Res., 24: 39-59.

CURTIS, W.M., 1963: THE STUDENT'S FLORA OF TASMANIA, PART II. Government Printer, Hobart.

CURTIS, W.M., 1967: THE STUDENT'S FLORA OF TASMANIA, PART III. Government Printer, Hobart.

CURTIS, W.M. \& MORRIS, D.I, 1975: THE STUDENT'S FLORA OF TASMANIA, PARTI. Second edition. Government Printer, Hobart.

FAEGRI, K. \& IVERSEN, J., 1975: TEXTBOOK OF POLLEN ANALYSIS. Third edition. Hafner, New York.

GIBSON, N. \& KIRKPATRICK, J.B., 1985a: Vegetation and flora associated with localized snow accumulation at Mount Field West, Tasmania. Aust. J. Ecol., 10: 91-99.

GIBSON, N. \& KIRKPATRICK, J.B., 1985b: A comparison of the cushion plant communities of New Zealand and Tasmania. N.Z. J. Bot., 23: 549-566.

GODLEY, E.J., 1978: Cushion bogs. In Troll, C. \& Laver, W. (Eds): GEOECOLOGICAL RELATIONS BETWEEN THE SOUTHERN TEMPERATE ZONE AND THE TROPICAL MOUNTAINS. Franz Steiner Verlag GMBH, Wiesbaden: 141-158.

JACKSON, W.D., 1972: Vegetation of the Central Plateau. In Banks, M.R. (Ed.): THE LAKE COUNTRY OF TASMANIA. Royal Society of Tasmania, Hobart: 61-68.

KIERNAN, K., 1980: PLEISTOCENE GLACIATION OF THE CENTRAL WEST COAST RANGE, TASMANIA. Unpubl. Honours thesis, University of Tasmania.

KIERNAN, K., 1983a: Relationship of cave fills to glaciation in the Nelson River Valley, central Western Tasmania. Aust. Geogr., 15: 367-375.
KIERNAN, K, 1983b: Weathering evidence for an additional glacial stage in Tasmania. Aust. Geogr. Stud., 21: 197-120.

KIERNAN, K., 1985: LATE CAINOZOIC GLACIATION AND MOUNTAIN GEOMORPHOLOGY IN THE CENTRAL HIGHLANDS OF TASMANIA. Unpubl. Ph.D. thesis, University of Tasmania: 2 vols.

KIRKPATRICK, J.B., 1977: Vegetation of the West Coast Region. In Banks, M.R. \& Kirkpatrick, J.B. (Eds): LANDSCAPE AND MAN. Royal Society of Tasmania, Hobart: $55-80$.

KIRKPATRICK, J.B., 1980: Tasmanian high mountain vegetation. I. A reconnaissance survey of the eastern Arthur Range and Mt. Picton. Pap. Proc. R. Soc. Tasm., 114: 1-20.

KIRKPATRICK, J.B., 1982: Phytogeographical analysis of Tasmanian alpine floras. J. Biogeogr., 9: 255-271.

KIRKPATRICK, J.B., 1983: Treeless plant communities of the Tasmanian high country: their typology, dynamics and conservation. Proc. Ecol. Soc. Austr., 12: 61-77.

KIRKPATRICK, J.B. \& GIBSON, N., 1984: Dynamics of a Tasmanian bolster heath string fen. Vegetatio, 56: 71-78.

KIRKPATRICK, J.B. \& HARWOOD, C.E., 1980: Vegetation of an infrequently burned Tasmanian mountain region. Proc. $R$. Soc. Vict., 91: 79-107.

MARTIN, D., 1940: The vegetation of Mt. Wellington, Tasmania. Pap. Proc. R. Soc. Tasm., 9: 97-124.

MacPHAIL, M.K., 1975: Late Pleistocene environments in Tasmania. Search, 6: 295-300.

MacPHAIL, M.K., 1979: Vegetation and climates in southern Tasmania since the last glaciation. Quat. Res., 11: 306-341.

MacPHAIL, M.K. \& COLHOUN, E.A., 1985: Late Last Glacial vegetation, climates and fire activity in southwest Tasmania. Search, 16: 43-45.

MacPHAIL, M.K. \& McQUEEN, D.R., 1983: The value of New Zealand pollen and spores as indicators of Cainozoic vegetation and climates. Tuatara, 2: 37-59.

SANSOM, P.W., 1978: THE GLACIAL GEOMORPHOLOGYOF THETULLAH AREA. Unpubl. Honours thesis, University of Tasmania.

(accepted 28 November 1986) 